\title{
POWIĄZANIA SIECIOWE A ROZWÓJ PRZEDSIĘBIORCZOŚCI MIĘDZYNARODOWEJ
}

Z a r y s t r e ś c i: Wzrost konkurencji międzynarodowej, w tym coraz intensywniejsza obecność podmiotów zagranicznych na rynkach lokalnych, skutkuje poszukiwaniem nowych sposobów przetrwania i rozwoju przedsiębiorstw. Współczesne uwarunkowania gospodarcze wymuszają na przedsiębiorstwach tworzenie różnorodnych powiązań o charakterze sieciowym, traktowanych jako koncepcja internacjonalizacji ich działalności. Artykuł zawiera rozważania dotyczące możliwych interakcji zachodzących pomiędzy tzw. podejściem sieciowym (network approach) oraz przedsiębiorczością międzynarodową.

S ł o w a k l u c z o w e: internacjonalizacja przedsiębiorstwa; organizacja sieciowa; przedsiębiorczość międzynarodowa.

Klasyfikacja JEL: F23.

\section{WSTĘP}

Problematyka przedsiębiorczości zyskuje na znaczeniu w warunkach procesu globalizacji gospodarki i wzrostu umiędzynarodowienia (internacjonalizacji) przedsiębiorstw. Koncepcja przedsiębiorczości międzynarodowej powstała jako obszar wspólny dwóch domen badawczych: przedsiębiorczości i biznesu międzynarodowego, czyli z jednej strony jej podstaw teoretycznych dostarczają teorie i koncepcje przedsiębiorczości, z drugiej

\footnotetext{
* Adres do korespondencji: Ireneusz Drabik, Wyższa Szkoła Zarządzania Marketingowego i Języków Obcych w Katowicach, Wydział Ekonomiczno-Inżynieryjny, Katedra Marketingu, ul. Gallusa 12,40-594 Katowice, e-mail: i.drabik@wp.pl.
} 
zaś - teorie ekonomiczne internacjonalizacji przedsiębiorstwa [Kraśnicka, 2008, s. 13]. W aktualnych warunkach przedsiębiorczość jest kategorią wielowymiarową, na którą wpływa wiele zmiennych. Przyjmuje się, że przedsiębiorczość może wyrażać się we wszystkich dziedzinach działalności przedsiębiorstwa, np. w szybkim wprowadzaniu postępu techniczno-organizacyjnego czy w dynamicznych działaniach na rynku międzynarodowym. Celem artykułu jest przedstawienie tzw. podejścia sieciowego (network approach) jako koncepcji internacjonalizacji przedsiębiorstwa i elementu przedsiębiorczości międzynarodowej. W artykule przyjęto istnienie interakcji pomiędzy powiązaniami sieciowymi oraz przedsiębiorczością międzynarodową.

\section{PRZEDSIĘBIORCZOŚĆ MIĘDZYNARODOWA}

Kategoria przedsiębiorczości po raz pierwszy pojawiła się w literaturze ekonomicznej w połowie XVIII wieku. Wprowadził ją francuski ekonomista R. Cantillon, który nazywał przedsiębiorcami kupców dostrzegających różnice cen na różnych rynkach i potrafiących wykorzystać je dla własnej korzyści. R. Cantillon zwrócił uwagę na ryzyko ekonomiczne związane z tego typu działalnością, polegające na niepewności co do znalezienia nabywcy na produkt i uzyskania odpowiednio wysokiej ceny [Godziszewski i in., 2011, s. 20-21].

Problematyka dotycząca przedsiębiorczości niezwykle popularna stała się w XX wieku, a zapoczątkowała ją fundamentalna praca J. Schumpetera pt. „Teoria rozwoju gospodarczego”. W pracy tej przedsiębiorczość uznano za siłę napędową gospodarki kapitalistycznej. Zdaniem J. Schumpetera zachowania przedsiębiorcze cechują ludzi pełnych pomysłów, inicjatyw i wytrwałości w pokonywaniu barier, łamaniu stereotypów, uodpornionych na stresy i porażki. Działanie tego mechanizmu polega na tym, że przedsiębiorcy stale poszukują nowych, nie stosowanych poprzednio kombinacji czynników wytwórczych (innowacji). Rozwój dokonuje się przez „twórczą destrukcję", czyli burzenie równowagi i uruchomienie procesów dostosowawczych, które - za pomocą mechanizmu konkurencji - eliminują nieefektywne zastosowania czynników wytwórczych i promują nowe, efektywne [Koźmiński, 2004, s. 162-163].

Przedsiębiorczość ma kluczowe znaczenie dla rozwoju ekonomicznego. W aktualnych warunkach niepewności otoczenia przedsiębiorcy są podstawowymi nośnikami rozwoju, jego głównymi beneficjentami, ale 
jednocześnie przegranymi w przypadku nieudanych przedsięwzięć. Przedsiębiorczość jest zasadniczym warunkiem sukcesu na współczesnym konkurencyjnym rynku - warunkiem przetrwania i rozwoju indywidualnych oraz zbiorowych uczestników rynku. Wzrost niepewności otoczenia sprzyja wzrostowi znaczenia przedsiębiorczości, ponieważ powtarzanie sprawdzonych rozwiązań szybko staje się coraz mniej opłacalne.

Organizacje, chcące sprostać globalnej konkurencji, powinny wypracować odpowiedni model działań przedsiębiorczych, ukierunkowanych na zwiększenie zakresu umiędzynarodowienia swoich strategii. W definicjach internacjonalizacji przedsiębiorstwa kładzie się nacisk na aspekt przedmiotowy i przestrzenny. Zgodnie z ogólną definicją J. Rymarczyka, internacjonalizacja przedsiębiorstwa oznacza „każdy rodzaj działalności gospodarczej podejmowanej przez przedsiębiorstwo za granicą" [Rymarczyk, 2004, s. 19]. W tym szerokim ujęciu stosowanie pojęcia internacjonalizacja jest niezależne od osiągniętego stopnia intensywności i zaangażowania przedsiębiorstwa na rynkach zagranicznych. Z. Pierścionek pod pojęciem internacjonalizacji przedsiębiorstwa rozumie „każdą formę i zakres powiązań jego różnych działalności z rynkami zagranicznymi" [Pierścionek, 2003, s. 454]. Z kolei M. Strzyżewska wskazuje, że internacjonalizacja polega na ,geograficznym poszerzaniu zakresu działania firm i w konsekwencji prowadzi do globalizacji tych działań" [Strzyżewska, 2005, s. 419].

Współczesne rozumienie internacjonalizacji przedsiębiorstwa powinno być rozpatrywane na różnych płaszczyznach, co umożliwia wyróżnienie tzw. internacjonalizacji czynnej i biernej. W literaturze przedmiotu powyższe rozróżnienie jest przeprowadzane z uwzględnieniem różnych kryteriów, w tym zmiany warunków działania (tj. miejsca konkurowania przedsiębiorstwa z podmiotami zagranicznymi - rynki zagraniczne i rynek krajowy), stopnia samodzielności przedsiębiorstwa $\mathrm{w}$ realizacji strategii internacjonalizacji (form internacjonalizacji i zakresu współpracy z partnerami zagranicznymi) oraz stopnia umiędzynarodowienia różnych ogniw w łańcuchu tworzenia wartości w przedsiębiorstwie [Limański, Drabik, 2010, s. 16].

Wejście przedsiębiorstwa na rynki zagraniczne (bez względu na stopień (zakres) zagranicznego zaangażowania zasobów) zmienia warunki jego działania - konkurowanie przez poszerzenie działania na rynki zagraniczne określa się jako internacjonalizację czynną. Jednak w warunkach globalizacji zmieniają się także warunki funkcjonowania przedsiębiorstwa ograniczającego swoją działalność do rynku krajowego, który jest przedmiotem ekspansji podmiotów zagranicznych. Sytuację, w której przedsiębiorstwo krajowe jest zmuszone do konkurowania na rynku macierzystym z przed- 
siębiorstwami zagranicznymi, można określić jako internacjonalizację bierną [Strzyżewska, 2005, s. 419].

Niektórzy autorzy dokonują rozróżnienia internacjonalizacji czynnej i biernej w kontekście stopnia samodzielności przedsiębiorstwa w realizacji strategii umiędzynarodowienia, ze szczególnym uwzględnieniem aktywnych i biernych form internacjonalizacji i współpracy z partnerami zagranicznymi. Internacjonalizacja czynna oznacza w tym przypadku samodzielną ekspansję zagraniczną przedsiębiorstwa w różnych możliwych formach z wykorzystaniem zasobów własnych. $\mathrm{Z}$ kolei internacjonalizacja bierna to wchodzenie w różnorodne związki z partnerami zagranicznymi, któremu niekoniecznie musi towarzyszyć realizacja sprzedaży poza granicami kraju lokalizacji danego przedsiębiorstwa. Internacjonalizacja bierna polega na międzynarodowych połączeniach przedsiębiorstw, powoływaniu wspólnych przedsięwzięć, zawiązywaniu kontraktów i porozumień w celu obsługi rynku krajowego (macierzystego) i ewentualnie rynków zagranicznych [Rymarczyk, 2004, s. 28-29].

W literaturze przedmiotu można znaleźć rozróżnienie internacjonalizacji czynnej i biernej z uwzględnieniem kryterium stopnia umiędzynarodowienia różnych ogniw w łańcuchu tworzenia wartości w przedsiębiorstwie. Wśród podstawowych ogniw w tym łańcuchu wymienia się: badania rozwojowe i wdrożeniowe, projektowanie technologiczne i przemysłowe, zakupy maszyn i urządzeń oraz surowców i materiałów, produkcję, marketing, sprzedaż i dystrybucję, serwis. Internacjonalizacja czynna będzie utożsamiana ze sprzedażą produktów przedsiębiorstwa na rynkach zagranicznych, której towarzyszą określone działania marketingowe (internacjonalizacja rynków zbytu). W przypadku gdy przedsiębiorstwo funkcjonuje tylko na rynku krajowym (macierzystym), ale wchodzi w relacje z rynkami zagranicznymi w trakcie kształtowania pozostałych elementów łańcucha tworzenia wartości, to zjawisko takie określić można jako internacjonalizację bierną (internacjonalizacja rynków czynników produkcji) [Gorynia, 2007, s. 35-36].

Identyfikacja kategorii internacjonalizacji czynnej i biernej (w różnych kontekstach) pozwala na stwierdzenie, że we współczesnej gospodarce większość przedsiębiorstw ma określone powiązania z podmiotami zagranicznymi (zwłaszcza w odniesieniu do koncepcji powiązań sieciowych). Tym samym za właściwe uznaje się stosowanie pojęcia przedsiębiorczości międzynarodowej, która już ze swojego założenia przekracza granice krajowe. Występujący w ramach powyższych powiązań aktorzy (przedsiębiorstwa, instytucje, jednostki) są bowiem podmiotami międzynarodo- 
wymi. Zdaniem niektórych autorów w warunkach silnie zglobalizowanej gospodarki w odniesieniu do zarządzania przedsiębiorstwem możemy mówić przede wszystkim o przedsiębiorczości międzynarodowej [Nowacki, 2014, s. 16]. Z drugiej strony, pojęcie przedsiębiorczości międzynarodowej stosunkowo rzadko występuje w krajowej literaturze przedmiotu. Jeśli już badacze odnoszą się do przedsiębiorczości międzynarodowej, to czynią to poprzez nadawanie ogólnemu pojęciu przedsiębiorczości szeregu cech przedsiębiorczości międzynarodowej, albo też podane znaczenie różni się od tego znanego i dotyczy po prostu prowadzenia działalności gospodarczej na rynkach zagranicznych z zastosowaniem różnych form internacjonalizacji [Morawczyński, 2008].

Analiza definicji przedsiębiorczości międzynarodowej prezentowanych w zagranicznej literaturze przedmiotu pozwala stwierdzić, że pojęcie to ewoluowało. Początkowo autorzy skupiali się przede wszystkim na nowych międzynarodowych przedsięwzięciach, aby później zwrócić uwagę na przedsiębiorczość korporacyjną. B. M. Oviatt i P. P. McDougall w kolejnych publikacjach wzbogacali pojęcie przedsiębiorczości międzynarodowej, wykorzystując dorobek wszystkich ważnych współczesnych teorii przedsiębiorczości. Dążąc do zdefiniowania przedsiębiorczości międzynarodowej, stwierdzili, że jest to kombinacja zachowań innowacyjnych, proaktywnych i zorientowanych na ponoszenie ryzyka, przekraczających granice państw i ukierunkowanych na tworzenie wartości w organizacjach. W innym ujęciu wspomniani autorzy zdefiniowali analizowane pojęcie jako proces odkrywania, tworzenia, oceny i wykorzystywania okazji - ponad granicami państw - w celu kreowania nowych produktów i usług [Kraśnicka, 2008, s. 11-12]. Szerokie podejście do koncepcji przedsiębiorczości międzynarodowej może odpowiedzieć na pytanie, co dzieje się z przedsiębiorstwem $\mathrm{w}$ procesie internacjonalizacji, a nie tylko, w jaki sposób przedsiębiorstwo wchodzi na nowe rynki zagraniczne. Istnieje jednak luka badawcza w odniesieniu do wpływu, jaki wywiera przedsiębiorczość na wyniki osiągane przez dany podmiot, a także znaczenia tych relacji w różnych państwach.

\section{INTERNACJONALIZACJA PRZEDSIĘBIORSTWA W PODEJŚCIU SIECIOWYM}

Proces globalizacji gospodarki i towarzysząca mu postępująca dywersyfikacja działalności przedsiębiorstw, zarówno geograficzna, jak i kulturowa, 
powodują konieczność zapewnienia dostępu i wykorzystania „lokalnej” wiedzy dotyczącej konkretnych rynków, procesów, produktów, technologii. Otoczenie staje się coraz bardziej niepewne, co z jednej strony wymaga umiejętności szybkiej reakcji na zachodzące zmiany rynku i technologii, a z drugiej wskazuje na konieczność rozłożenia ryzyka działalności. Wymagana szybkość reakcji nie pozwala na powolne tworzenie w jednym przedsiębiorstwie kompletnej wiedzy i umiejętności oraz gromadzenie niezbędnych zasobów umożliwiających efektywne funkcjonowanie. Charakter współczesnego otoczenia, jego turbulencja, wymaga zmiany zasad funkcjonowania przedsiębiorstw [Limański, Drabik, 2013].

W tzw. podejściu sieciowym (network approach) zwraca się uwagę na uwzględnienie kontekstu społecznego zachowań przedsiębiorstwa, który polega na traktowaniu przedsiębiorstwa jako fragmentu szerszego systemu wielu podmiotów wzajemnie na siebie oddziałujących. Teoria podejścia sieciowego zakłada, że internacjonalizacja przedsiębiorstwa stanowi element rozwoju powiązań (więzi) i interakcji między dostawcami a ich klientami zagranicznymi oraz innymi podmiotami. Podejście sieciowe określa całokształt powiązań istniejących pomiędzy przedsiębiorstwami, które niekoniecznie muszą przyjmować formalne struktury. Najważniejszym założeniem podejścia sieciowego jest współpraca dwóch lub więcej podmiotów, z możliwością zachowania istniejących pomiędzy nimi stosunków konkurencyjnych. Koopetycja, stanowiąca połączenie kooperacji oraz konkurencji, służy osiągnięciu przez przedsiębiorstwo efektów lepszych od tych, które występowałyby w analogicznej sytuacji, gdyby określone podmioty nie nawiązały odpowiedniej relacji [Nowacki, 2014, s. 17].

Na powstanie i rozwój modelu sieciowego główny wpływ mają rozwój wiedzy i innowacji, co zarazem należy traktować jako niezwykle ważny czynnik procesu globalizacji gospodarki i turbulencji otoczenia. Dzięki zastosowaniu w procesach wytwórczych nowoczesnych technologii zyskują one większą elastyczność. Oznacza to, że produkowane wyroby i oferowane usługi mogą być lepiej dostosowane do coraz bardziej zindywidualizowanych potrzeb i wymagań konsumentów. Przemiany technologii zmieniają sposób ich pozyskiwania i asymilacji przez przedsiębiorstwa. Technologie stają się coraz bardziej skomplikowane, składniki technologii przekształcają się w podsystemy. Nowoczesne technologie wpływają także na zmniejszanie się dystansu dzielącego poszczególne etapy procesu produkcyjnego, począwszy od prac w zakresie $\mathrm{B}+\mathrm{R}$, poprzez produkcję, aż do dystrybucji. Łatwość pozyskiwania, przetwarzania i wykorzystania informacji z wyko- 
rzystaniem nowoczesnych technologii powoduje, że działanie praw ekonomii nie ogranicza się już dłużej do całego łańcucha wartości, a zaczyna przeważać w poszczególnych jego ogniwach [Cyrson, 2002, s. 39-48].

W obecnych warunkach przedsiębiorstwa coraz częściej odwołują się do współdziałania z podmiotami zewnętrznymi (innymi przedsiębiorstwami i instytucjami), które autonomicznie rozwijają określone zdolności i zasoby. W ten sposób tworzone są swoiste sieci współdziałających ze sobą różnych podmiotów $\mathrm{w}$ wymiarze międzynarodowym. $\mathrm{Z}$ punktu widzenia danego przedsiębiorstwa okazuje się, że wyspecjalizowani partnerzy zewnętrzni są w stanie realizować określone działania taniej i lepiej, a wejście z nimi w relacje umożliwia koncentrację na rozwijaniu własnych podstawowych kompetencji, które decydują o przewadze konkurencyjnej przedsiębiorstwa na obsługiwanym rynku. Kryterium wyróżniającym podmioty wchodzące w skład sieci jest więc posiadanie specyficznego rodzaju wiedzy i umiejętności (np. wiedza służąca rozwojowi nowych produktów, wiedza dotycząca wytwarzania oraz zapewnienia jakości produktu, znajomość lokalnego rynku i potrzeb klienta), a podstawową funkcją sieci - dzielenie się wiedzą między podmiotami tworzącymi sieć. W ten sposób, jak określa to A. K. Koźmiński, dochodzi do dekompozycji struktur monolitycznych, polegającej na tym, że miejsce struktur organizacyjnych $\mathrm{z}$ jednym centralnym ośrodkiem kierowniczym, hierarchią i wyraźną strukturą zajmują organizacje sieciowe (określane również jako sieci międzyorganizacyjne), tworzone przez powiązane ze sobą i w różnym stopniu autonomiczne podmioty, które wspólnie realizują określone działania. Powstałe sieci mają charakter ,pulsujący”, tzn. odznaczają się zmiennym składem, zmienną siłą powiązań, a przede wszystkim zmiennymi celami i zadaniami [Koźmiński, 2004, s. 39-41].

Podejście sieciowe tworzy nową perspektywę rozumienia internacjonalizacji przedsiębiorstwa. Funkcjonowanie przedsiębiorstwa w międzynarodowej sieci stwarza możliwości lepszej orientacji co do rozwoju aktywności na rynkach zagranicznych poprzez nawiązywanie nowych kontaktów $\mathrm{z}$ podmiotami zagranicznymi. Internacjonalizacja przedsiębiorstwa w omawianym podejściu jest ściśle uwarunkowana charakterem, intensywnością i rozwojem różnorodnych więzi w ramach sieci, osiągniętej w jej ramach pozycji, jak również przyszłymi możliwościami stwarzanymi przez dany system powiązań [Limański, Drabik, 2010, s. 70].

Organizacja sieciowa powstaje z udziałem tych podmiotów rynkowych, które charakteryzuje określonego typu zbieżność, co można rozumieć jako podobieństwo bądź tożsamość domeny (produktu, rynku, grupy docelowej 
nabywców), stosowanych technologii, wiedzy i sposobów działania. Jeśli podmioty nie wykazują takiej zbieżności, to z definicji nie mogą osiągać efektu synergicznego. Poniżej przedstawiono grupy podmiotów, których wejście w układ współdziałania typu sieciowego jest prawdopodobne [Łobos, 2005, s. 163-164]:

- Podmioty reprezentujące tę samą domenę działania w sensie przedmiotowym, chociaż niekoniecznie w sensie rynku rozumianego terytorialnie. Są to więc podmioty stanowiące grupę strategiczną bezpośrednią (działając na tym samym rynku) bądź potencjalną konkurencję (działając na różnych rynkach). Charakteryzuje je zależność od tej samej (terytorialnie lub z uwagi na cechy) grupy nabywców docelowych.

- Podmioty, które mają pokrewne, lecz nie identyczne w sensie przedmiotowym domeny i działają na tych samych bądź innych rynkach.

- Podmioty reprezentujące różne domeny, lecz komplementarne w sensie przedmiotowym. Ich kompetencje złożone w całość mogą zostać wykorzystane do skompletowania pewnej oferty rynkowej.

- Podmioty reprezentujące różne domeny, lecz takie, które łączą te same kompetencje (np. techniczne), wiedzę, umiejętności, know-how. Zbieżność polega na tworzeniu wyspecjalizowanych tego typu wartości, dysponowaniu nimi i ich wykorzystywaniu.

- Podmioty składających się z dużego podmiotu - operatora - oraz wielu małych podmiotów realizujących jego koncepcję rynkową.

W praktyce można wyróżnić sieci zdominowane oraz sieci równorzędnych partnerów. Zaklasyfikowanie sieci do jednej z powyższych grup daje odpowiedź na pytanie: czyją strategią jest strategia realizowana $\mathrm{w}$ ramach układu. Odpowiedź na pytanie ma pierwszorzędne znaczenie, gdyż sieci są narzędziem realizacji określonych strategii w układach współdziałania przedsiębiorstw. Możliwe jest więc, że jest to strategia realizowana przez jeden z podmiotów układu, podmiot centralny (sieć zdominowana), bądź też jest raczej wspólną strategią większości bądź nawet wszystkich podmiotów sieci (sieć równorzędnych partnerów). W pierwszym przypadku organizacja sieciowa przyjmuje postać sieci niesymetrycznej - dominuje w niej podmiot centralny, który formułuje strategię i koordynuje działalność całego układu. W drugim przypadku sieć międzyorganizacyjna ma charakter symetryczny, tzn. strategia jest wspólnie formułowana, a koordynacja opiera się na wzajemnych uzgodnieniach. Tworzy się wówczas sieć w postaci swoistego grona bądź organizacji modularnej [Zydlewska, 2003, s. 170-171; Łobos, 2005, s. 169-172]. 
We współczesnych sieciach o charakterze zdominowanym główną rolę odgrywają duże korporacje transnarodowe [Drabik, 2014a, s. 17-30; Drabik, 2014b, s. 107-118; Drabik, Križovský, Dufinec, 2010, s. 73-82]. Wymienia się wewnątrzorganizacyjne sieci dużych korporacji (określane również jako wewnątrzkorporacyjne) oraz sieci podmiotów (dostawców) skupionych wokół korporacji wiodącej. Sieci wewnątrzkorporacyjne tworzone są przez grupy jednostek organizacyjnych w ramach współczesnych korporacji transnarodowych z ich własnością udziałów w filiach. Sieć wewnątrzkorporacyjna może mieć przy tym postać jednolitej i zwartej struktury lub luźniejszego ugrupowania filii działających w różnych krajach, co zależy od przyjętego modelu organizacji i zarządzania w danej korporacji. Z kolei sieci dostawców składają się z wielu hierarchicznie powiązanych „warstw” uczestników, począwszy od wiodącej korporacji, określanej również mianem lidera marki, dysponującej powszechnie rozpoznawanym znakiem firmowym, która ma dominującą pozycję w sieci, aż do małych lokalnych wąsko wyspecjalizowanych dostawców. Głównym celem korporacji funkcjonujących na powyższych zasadach jest zapewnienie szybkiego i taniego dostępu do zasobów, zdolności oraz wiedzy, niezbędnych z punktu widzenia przedmiotu ich działalności [Zorska, 2007, s. 199-203].

Powstawanie sieci współdziałania równorzędnych partnerów staje się coraz ważniejsze w przedsiębiorstwach zmuszonych do szybkiego reagowania na sytuacje $\mathrm{w}$ ich otoczeniu rynkowym. Kooperacja w sieci jest formą reakcji na szybki postęp nauki i wzrost przedsiębiorczości. Chodzi bowiem o to, aby szybko i efektywnie łączyć ludzi, kapitał i środki techniczne w procesach wytwórczych, przełamując granice poszczególnych podmiotów. Sieci kooperacyjne równorzędnych podmiotów składają się $\mathrm{z}$ formalnie niezależnych przedsiębiorstw ogniskujących $\mathrm{w}$ sobie jedynie podstawowe umiejętności (core competence), dające w danej konfiguracji przewagę konkurencyjną całej sieci. Podstawą innowacyjności jest złożony układ wzajemnych powiązań między umiejętnościami różnych przedsiębiorstw, które łączy ze sobą nie tylko przepływ dóbr i usług, lecz także w coraz większym stopniu - przepływ wiedzy. Czas takiej współpracy jest bardzo często ograniczony do realizacji danego przedsięwzięcia, a konfiguracja partnerów zmienna.

Wśród podstawowych czynników wpływających na sukces sieci, bez względu na jej rodzaj i charakter współpracy, wymienić można przede wszystkim [Fonfara, Ratajczak-Mrozek, 2009, s. 42-43]:

- Szybkość reakcji na zmiany w otoczeniu. Podmioty współpracujące ze sobą muszą być wrażliwe na zmiany otoczenia oraz szybko na nie 
reagować. Warto przy tym zaznaczyć, że pojedynczemu przedsiębiorstwu łatwiej jest dostosować się do sytuacji rynkowej w porównaniu z podmiotami, które nie działają w sposób niezależny. Szybka reakcja na zmiany otoczenia może zająć znaczenie więcej czasu zwłaszcza w przypadku wielu powiązanych ze sobą przedsiębiorstw.

- Wysoki poziom zaufania między partnerami. Im dłuższy okres współpracy, tym z reguły większe zaufanie wśród uczestników sieci. Zaufanie jest możliwe do zbudowania jedynie w wyniku dobrze przebiegającej długotrwałej współpracy - żaden z partnerów nie może go narzucać ani wykorzystywać w oportunistycznych celach.

- Sprawne rozprzestrzenianie informacji wewnątrz sieci. Komunikacja powinna obejmować zarówno poziome, jak i pionowe przekazywanie informacji. Stwarza to możliwość zapoznania się z ewentualnymi problemami występującymi nie tylko w danym przedsiębiorstwie, ale również w tych, z którymi ono współpracuje w ramach sieci. Dzięki nowoczesnym technologiom odległe od siebie jednostki mogą być w stałym kontakcie i bardzo szybko reagować na potencjalne zagrożenia.

Efektem ewolucji podejścia sieciowego jest powstanie tzw. strategicznej sieci biznesowej. U podstaw rozróżnienia tradycyjnego podejścia sieciowego i strategicznej sieci biznesowej znajdują się różne przesłanki powstawania sieci. Tradycyjne sieci biznesowe powstają w trakcie współpracy pomiędzy przedsiębiorstwami, które dzielą się swoimi zasobami oraz budują wzajemne zaufanie, dostosowując swoje zachowania, co przyczynia się do usprawnienia funkcjonowania sieci i osiągania celów jej uczestników. Wraz z upływem czasu, wzrostem zaufania pomiędzy partnerami oraz wypracowywaniem coraz bardziej znaczącej przewagi konkurencyjnej, uczestnicy sieci mogą decydować się na angażowanie coraz bardziej zaawansowanych i kosztownych zasobów. Z kolei koncepcja strategicznej sieci biznesowej opiera się na założeniu, że powiązania powstają w wyniku długoterminowej strategii głównego przedsiębiorstwa. Inicjator, a później dominujący podmiot sieci w celu osiągnięcia zamierzonych, strategicznych celów decyduje się na generowanie powiązań w ramach samodzielnie organizowanej sieci, umożliwiających pozyskiwanie potrzebnych produktów i usług oraz wymianę zasobów, w tym wiedzy, z innymi podmiotami [Fonfara, Ratajczak-Mrozek, 2009, s. 40-41]. 


\section{PODSUMOWANIE}

Problematyka dotycząca sieci staje się jednym z najbardziej aktualnych obszarów badań funkcjonowania przedsiębiorstw i rynku oraz zarządzania przedsiębiorstwem z punktu widzenia poprawy efektywności i pozycji strategicznej. Podejście sieciowe, które podkreśla rolę i znaczenie powiązań przedsiębiorstwa $\mathrm{w}$ procesie umiędzynarodowienia $\mathrm{z}$ różnymi podmiotami otoczenia, tj. nabywcami, dostawcami, konkurentami i innymi uczestnikami rynków zagranicznych, może być traktowane jako koncepcja internacjonalizacji współczesnego przedsiębiorstwa, w tym w odniesieniu do małych i średnich podmiotów gospodarczych [Drabik, 2009, s. 352-361]. Dzięki proaktywności przedsiębiorstwa nawiązują kontakty z innymi podmiotami na rynkach zagranicznych, z którymi współpracują przy realizacji określonych działań, istnieje więc interakcja pomiędzy podejściem sieciowym a przedsiębiorczością międzynarodową. Co więcej, pozyskane kontakty udostępniają w ramach sieci, w której funkcjonują, co pozwala na dalszą intensyfikację posiadanej wiedzy oraz poziomu innowacyjności. Z drugiej strony, należy pamiętać o określonych zagrożeniach, w tym na przykład możliwości utraty wyjątkowych zasobów, istnieniu ryzyka współpracy z niewłaściwymi podmiotami zagranicznymi ze względu na brak wcześniejszego doświadczenia, czy w obawie przed utratą kontroli nad przedsiębiorstwem.

\section{LITERATURA}

Cyrson E. (2002), Nowy paradygmat strategii konkurencji, [w:] Skawińska E. (red.), Konkurencyjność przedsiębiorstw - nowe podejście, WN PWN, Warszawa - Poznań.

Drabik I. (2014a), Bezpośrednie inwestycje zagraniczne jako forma ekspansji przedsiębiorstwa i ich wpływ na gospodarkę, [w:] Cisek M., Nowogródzka T. (red.), Stabilność organizacji we wspótczesnej gospodarce, Wydawnictwo Studio Emka, Warszawa.

Drabik I. (2014b), Tendencje zmian w przeplywach bezpośrednich inwestycji zagranicznych we wspótczesnej gospodarce światowej, [w:] Brzóska J., Pyka J. (red.), Organizacja i zarzadzanie. Zeszyt 73. Nowoczesność przemystu i ustug. Zeszyty Naukowe Politechniki Ślaskiej Nr 1919, Politechnika Śląska, Gliwice. 
Drabik I. (2009), Strategia internacjonalizacji przedsiębiorstwa - podejście sieciowe, [w:] Pyka J. (red.), Nowoczesność przemystu i ustug. Konkurencja $i$ kooperacja $w$ strategiach zarzadzania organizacjami, TNOiK - Oddział w Katowicach, AE w Katowicach, Politechnika Śląska, Katowice.

Drabik I., Križovský S., Dufinec I. (2010), Korporacje transnarodowe - istota $i$ strategie ekspansji w otoczeniu globalnym, [w:] Limański A., Milic-Czerniak R. (red.), Funkcjonowanie podmiotów gospodarczych $w$ warunkach niepewności, WSZMiJO, Katowice.

Fonfara K., Ratajczak-Mrozek M. (2009), Proces internacjonalizacji firmy w świetle podejścia sieciowego, [w:] Fonfara K. (red.), Zachowanie przedsiębiorstwa w procesie internacjonalizacji. Podejście sieciowe, PWE, Warszawa.

Godziszewski B., Haffer M., Stankiewicz M. J., Sudoł S. (2011), Przedsiębiorstwo. Teoria i praktyka zarzadzania, PWE, Warszawa.

Gorynia M. (2007), Strategie zagranicznej ekspansji przedsiębiorstw, PWE, Warszawa.

Koźmiński A. K. (2004), Zarządzanie w warunkach niepewności. Podręcznik dla zaawansowanych, WN PWN, Warszawa.

Kraśnicka T. (2008), Przedsiębiorczość międzynarodowa jako odrębny obszar badań, [w:] Kraśnicka T. (red.), Przedsiębiorczość międzynarodowa. Aspekty teoretyczne i praktyczne, AE, Katowice.

Limański A., Drabik I. (2010), Marketing międzynarodowy, Difin, Warszawa.

Limański A., Drabik I. (2013), Zarządzanie bezpieczeństwem ekonomicznym w warunkach niepewności, WSZMiJO, Katowice.

Łobos K. (2005), Organizacje sieciowe, [w:] Krupski R. (red.), Zarzadzanie przedsiębiorstwem w turbulentnym otoczeniu, PWE, Warszawa.

Morawczyński R. (2008), Przedsiębiorczość międzynarodowa, UE, Kraków.

Nowacki F. (2014), Przedsiębiorczość międzynarodowa a relacje sieciowe-wpływ na ksztaltowanie wspótpracy na rynku ustug, „Marketing i Rynek”, nr 11.

Pierścionek Z. (2003), Strategie konkurencji i rozwoju przedsiębiorstwa, WN PWN, Warszawa.

Rymarczyk J. (2004), Internacjonalizacja i globalizacja przedsiębiorstwa, PWE, Warszawa.

Strzyżewska M. (2005), Marketing na rynkach zagranicznych, [w:] Nowakowski M. K. (red.), Biznes międzynarodowy. Od internacjonalizacji do globalizacji, SGH, Warszawa.

Zorska A. (2007), Korporacje transnarodowe. Przemiany, oddziatywania, wyzwania, PWE, Warszawa. 
Zydlewska A. (2003), Decyzje strategiczne w marketingu na rynku instytucjonalnym, [w:] Gołębiowski T. (red.), Marketing na rynku instytucjonalnym, PWE, Warszawa.

\title{
NETWORK CONNECTIONS VS DEVELOPMENT OF INTERNATIONAL ENTERPRISE
}

\begin{abstract}
The increase in international competition, including more and more intensive presence of overseas subjects on local markets, results in searching for new ways of enterprises' survival and development. Modern economic determinants force enterprises to create various connections of network nature functioning as internationalization conception of their activity. The article contains considerations concerning possible interaction between so called network approach and international enterprise.
\end{abstract}

Keywords: enterprise internationalization; network organization; international enterprise. 